\title{
Post-bleaching viability of expelled zooxanthellae from the scleractinian coral Pocillopora damicornis
}

\author{
Ross Hill, Peter J. Ralph*
}

Institute for Water and Environmental Resource Management and Department of Environmental Sciences, University of Technology, Sydney, PO Box 123, Broadway, New South Wales 2007, Australia

\begin{abstract}
Coral bleaching events have been linked to elevated seawater temperatures in combination with intense light and can be characterised by the loss of symbionts (zooxanthellae, genus Symbiodinium) from the host tissue, as well as a reduction in photosynthetic pigments in these zooxanthellae. The long-term (days) viability of expelled zooxanthellae in the water column from the scleractinian coral Pocillopora damicornis was explored in this study through measurements of photosynthetic health and morphological condition. After initial expulsion, zooxanthellae were found to be photosynthetically competent and structurally intact. However, within 6 to $12 \mathrm{~h}$ following this time, photosystem II photochemical efficiency dramatically declined in these cells and photosynthetic damage was gradually manifested in the loss of structural integrity of the cell. The time of expulsion during bleaching exposure, as well as ambient water temperature, greatly influenced survivorship. Expelled zooxanthellae were collected at 4 different time intervals $(0-6,6-12,12-24$ and $24-36$ h) following the onset of exposure to bleaching conditions $\left(32^{\circ} \mathrm{C}\right.$ and $400 \mu \mathrm{mol}$ photons $\left.\mathrm{m}^{-2} \mathrm{~s}^{-1}\right)$ and then maintained at 28,30 or $32^{\circ} \mathrm{C}$ and $100 \mu \mathrm{mol}$ photons $\mathrm{m}^{-2} \mathrm{~s}^{-1}$ for up to $96 \mathrm{~h}$. Those cells expelled within the first $6 \mathrm{~h}$ of bleaching and held at $28^{\circ} \mathrm{C}$ (lagoon temperature) had the greatest longevity, although even in this treatment, long-term photosynthetic viability was restricted to $5 \mathrm{~d}$ in the water column. This suggests that unless expelled zooxanthellae inhabit other environments of coral reefs (such as sediments) which may be more favourable for survival, their capacity for persistence in the environment is extremely limited.
\end{abstract}

KEY WORDS: Coral bleaching · Chlorophyll a fluorescence · Effective quantum yield · Pulse amplitude modulated $\cdot$ PAM $\cdot$ Zooxanthellae $\cdot$ Symbiodinium

\section{INTRODUCTION}

Symbiotic, dinoflagellate algae (zooxanthellae, genus Symbiodinium) reside in the endodermal tissue of coral hosts where they provide energy in the form of photosynthate to their mutualistic partner. In return, the animal supplies the zooxanthellae with metabolic and respiratory by-products and protection. This symbiotic relationship is at risk due to global climate change, which is resulting in a warming of the oceans at a rate of approximately 1 to $2^{\circ} \mathrm{C}$ per century (HoeghGuldberg 1999). The sensitivity of corals to this change is leading to an increase in the frequency, intensity and extent of mass coral bleaching events around the world (Hoegh-Guldberg 1999). These events occur during periods of elevated seawater temperatures, in combination with intense solar radiation, and can be characterised by the expulsion of zooxanthellae, as well as a reduction in the concentration of photosynthetic pigments (Hoegh-Guldberg \& Smith 1989).

The process by which zooxanthellae are expelled from the animal may be through host cell detachment (Gates et al. 1992, Brown et al. 1995) or exocytosis (Brown et al. 1995), and it is generally believed that this expulsion is a result of lost photosynthetic performance by the zooxanthellae. A number of photosynthetic sites of impact have been suggested (Iglesias-Prieto 1997, Jones et al. 1998, Warner et al. 1999, Takahashi et al. 2004, Tchernov et al. 2004, Hill \& Ralph 2006). It has also been suggested that the coral 
host plays an important, if not primary (Bhagooli \& Hidaka 2004b), role in determining the sensitivity of the holobiont to bleaching conditions with susceptibility and chance of mortality being dependent upon the combined physiological responses of both partners (Ralph et al. 2001, Bhagooli \& Hidaka 2004a).

Once zooxanthellae are removed from the host, they enter an aqueous environment and are subjected to major ionic shock (Goiran et al. 1997). Interestingly, freshly isolated zooxanthellae of several coral species can survive and remain healthy for at least $24 \mathrm{~h}$ (Bhagooli \& Hidaka 2003). However, the fate of expelled zooxanthellae under bleaching conditions is currently unresolved. Previous research has demonstrated that upon expulsion, zooxanthellae are initially photosynthetically competent (Ralph et al. 2001). This was supported by Bhagooli \& Hidaka (2004b), who found no difference in the photochemical efficiency of photosystem II (PSII) between freshly isolated and expelled zooxanthellae of a bleaching coral. These authors also classified a large proportion of the zooxanthellae released under bleaching conditions as healthy-looking zooxanthellae (Titlyanov et al. 1996). Further work by Ralph et al. (2005) showed that the health of expelled zooxanthellae varied depending on the coral species, the time of expulsion and the location within the host from where they were expelled (sun or shaded region). In contrast to these studies, using an alternative estimate of cell viability, Franklin et al. (2004, 2006) concluded that non-functional symbionts were expelled from Stylophora pistillata during bleaching events with cells displaying a degraded ultrastructure with disorganised cellular contents and permeable membranes. The length of exposure of corals to bleaching conditions has been suggested to explain these divergent results (Franklin et al. 2004, 2006), and here we tested the effect of time on expelled zooxanthellae viability.

Recovery of corals from bleaching events involves the repopulation of the host tissue with healthy zooxanthellae. The source of these dinoflagellates may be from division of residual photosynthetically healthy zooxanthellae still within the tissue or from the environment (Hayes \& Bush 1990, Jokiel \& Coles 1990, Jones \& Yellowlees 1997). Evidence of the potential for infection of the host tissue from the surrounding environment comes from juvenile corals of host species that do not transmit zooxanthellae vertically and whose eggs do not contain zooxanthellae (Richmond \& Hunter 1990). These juvenile corals may acquire zooxanthellae from a number of sources, including the water column (Jokiel \& Coles 1990), from corals releasing zooxanthellae (Stimson \& Kinzie 1991), from the sediment (free-living strain used by Carlos et al. 1999), from faecal material of fish and nudibranchs that prey on zooxanthellae-containing cnidarians (MullerParker 1984), or from direct contact with other healthy corals (Franzisket 1970). This provides support for the potential uptake of zooxanthellae by adult corals following a bleaching event. In addition, corals associate with a range of zooxanthellae types (LaJeunesse 2001), and changes in the genetic composition of the symbiont community have been found in coral hosts following bleaching events. This may be a result of a shift in the abundance of zooxanthellae types already harboured by the host (Berkelmans \& van Oppen 2006), or may indicate an uptake of new zooxanthellae clades from the environment, which has been shown in sponges (Hill \& Wilcox 1998), giant clams (BeldaBaillie et al. 1999), anemones (Kinzie et al. 2001) and octocorals (Lewis \& Coffroth 2004), but not convincingly (see Hoegh-Guldberg et al. 2002) in scleractinian corals (Baker 2001).

Although the capacity for corals to recover after a bleaching event depends on many factors (such as species, length and intensity of the bleaching event), a high proportion of affected corals have shown signs of recovery once temperatures drop back to the optimal range (Coles \& Brown 2003). It is therefore important to understand the fate of those zooxanthellae that are expelled, because if they have the potential to survive in the long-term, independent of the host, they may contribute to a stock of zooxanthellae available for reinfection following a bleaching event. This is the first study to investigate the post-bleaching viability of expelled zooxanthellae in the water column over several days. Photosynthetic health and morphological condition were assessed on zooxanthellae expelled from Pocillopora damicornis sub-colonies exposed to moderate bleaching conditions. Zooxanthellae were collected after 4 different time intervals following the onset of bleaching and were maintained in 3 different temperature treatments to determine their capacity for survival in the water column.

\section{MATERIALS AND METHODS}

Coral specimens. The coral species Pocillopora damicornis (Linnaeus) was collected from Heron Island lagoon located on the southern Great Barrier Reef of Australia $\left(152^{\circ} 06^{\prime} \mathrm{E}, 23^{\circ} 26^{\prime} \mathrm{S}\right)$ during January 2007. Four replicate sub-colonies (i.e. fragments of a coral colony $10 \mathrm{~cm}$ in diameter) were maintained in shaded aquaria $\left(<100 \mu \mathrm{mol}\right.$ photons $\left.\mathrm{m}^{-2} \mathrm{~s}^{-1}\right)$ at ambient lagoon temperature $\left(28^{\circ} \mathrm{C}\right)$ for approximately $2 \mathrm{~d}$ prior to experimentation.

Experimental protocol. Sub-colonies of Pocillopora damicornis were placed in 51 beakers in $0.45 \mu \mathrm{m}$ filtered seawater and held in a temperature controlled 
water bath (Julabo, EC, Labortechnik) at $28^{\circ} \mathrm{C}$. The seawater in each beaker was aerated with 2 bubblers to ensure adequate water circulation and gas exchange. Corals were exposed to $400 \mu \mathrm{mol}$ photons $\mathrm{m}^{-2} \mathrm{~s}^{-1}$ from halogen lights (Portable Floodlight, FL200, Arlec Lighting), and the temperature ramped over $6 \mathrm{~h}$ to $32^{\circ} \mathrm{C}$, which is an ecologically relevant rate for Heron Island lagoon (Jones \& Hoegh-Guldberg 2001). After $12 \mathrm{~h}$ illumination at $32^{\circ} \mathrm{C}$, the lights were switched off for $12 \mathrm{~h}$ and then turned back on. A Diving-pulse amplitude modulated (PAM) fluorometer (Walz) with a $6 \mathrm{~mm}$ fibre optic probe was used to measure the maximum quantum yield $\left(F_{\mathrm{v}} / F_{\mathrm{m}}\right)($ at $24 \mathrm{~h})$ and the effective quantum yield ( $\Phi_{\mathrm{PSII}}$ ) (at $0,6,12$ and $36 \mathrm{~h}$ ) of in hospite zooxanthellae, using a $0.8 \mathrm{~s}$ saturating pulse of $>4500 \mu \mathrm{mol}$ photons $\mathrm{m}^{-2} \mathrm{~s}^{-1}$ (gain =12).

Zooxanthellae were expelled from the coral tissue during exposure to bleaching conditions, and 4 discrete populations were collected at $0-6,6-12,12-24$ and 24-36 h. Following each collection interval, the coral specimen was returned to fresh filtered seawater $(0.45 \mu \mathrm{m})$ in a new 51 beaker at $32^{\circ} \mathrm{C}$. The suspended expelled zooxanthellae were collected on $0.45 \mu \mathrm{m}$ filter paper and resuspended in $140 \mathrm{ml}$ of fresh filtered seawater. Containers of $140 \mathrm{ml}$ in volume were used to house expelled zooxanthellae. Each container had 3 holes approximately $6 \mathrm{~cm}^{2}$ in size covered by $5 \mu \mathrm{m}$ mesh. This mesh size was effective in preventing the loss of zooxanthellae from the containers, but still allowed for water exchange. For each coral replicate, the expelled zooxanthellae at each time interval were placed into 3 containers. One container was placed into an aquarium of seawater maintained at $28^{\circ} \mathrm{C}$, one at $30^{\circ} \mathrm{C}$ and the third at $32^{\circ} \mathrm{C}$. Submersible pumps in each aquarium continually circulated the containers to ensure adequate water and gas exchange. Irradiance of $100 \mu \mathrm{mol}$ photons $\mathrm{m}^{-2} \mathrm{~s}^{-1}$ was applied to all 3 treatments on a 12:12 h light:dark ratio.

Upon collection of the 4 expelled zooxanthellae populations, a $3 \mathrm{ml}$ sample was placed in a Water-PAM fluorometer (Walz) cuvette. A saturating pulse was applied $\left(0.6 \mathrm{~s}\right.$ and $>3000 \mu \mathrm{mol}$ photons $\left.\mathrm{m}^{-2} \mathrm{~s}^{-1}\right)$ as soon as the fluorescence signal became steady, which took less than $10 \mathrm{~s}$ (photo-multiplier gain was between 18 and 30). To avoid changes in cell density, this sample was returned to the holding container following the fluorescence measurement. Subsequently, measurements of zooxanthellae density per $\mathrm{ml}$ and percentage of healthy-looking zooxanthellae and degraded zooxanthellae were performed. These fluorescence and visual assessments were repeated before the light was switched off each evening (19:00 h) and before the light was turned on each morning (07:00 h). Therefore, 07:00 h fluorescence measurements represented $F_{\mathrm{v}} / F_{\mathrm{m}}$ due to overnight dark-adaptation, while 19:00 h mea- surements were $\Phi_{\text {PSII }}$ as they were exposed to light over the day.

Characterisation of expelled zooxanthellae condition. The number of healthy-looking zooxanthellae $\left(H_{z}\right)$ and degraded zooxanthellae $\left(D_{z}\right)$ in each of the 4 populations was determined at regular intervals over the experimental period using a light microscope $(\times 400)$. Characterisation of $H_{\mathrm{z}}$ and $D_{\mathrm{z}}$ was performed following the descriptions by Titlyanov et al. (1996) and Bhagooli \& Hidaka (2004b), where $H_{z}$ were brown in colour, circular and with an intact cell wall; $D_{\mathrm{z}}$ were orange to dark brown in colour with an irregular shape, without a cell wall and less than half the size of $H_{\mathrm{z}}$. For each replicate $(\mathrm{n}=4)$, the visual characteristics of 15 cells were recorded and the average number of $H_{\mathrm{z}}$ was determined.

Zooxanthellae density determinations. In hospite zooxanthellae cell density $\left(\mathrm{cm}^{-2}\right)$ was measured prior to temperature ramping and after $36 \mathrm{~h}$ of exposure to bleaching conditions. Coral fragments were air brushed in $10 \mathrm{ml}$ of filtered seawater $(0.45 \mu \mathrm{m})$ to remove coral tissue from the skeleton. The slurry was centrifuged at $1000 \times g$ for $10 \mathrm{~min}$, and the pellet was resuspended in $10 \mathrm{ml}$ of filtered seawater and homogenised. Eight replicate cell counts were performed using a haemocytometer under a light microscope $(\times 200)$, and cell density was determined per $\mathrm{cm}^{2}$, following coral surface area calculations using the paraffin wax technique (Stimson \& Kinzie 1991). The expelled zooxanthellae density in each container was measured using the same technique on a haemocytometer with cell density per ml calculated from 8 replicate counts.

Statistical analysis. Repeated-measures analysis of variance (rmANOVA) was used to identify changes in $F_{\mathrm{V}} / F_{\mathrm{m}}$ and $\Phi_{\text {PSII }}$ of in hospite and expelled zooxanthellae and of the percentage of $H_{\mathrm{z}}$ over the time of the experiment $(\alpha=0.05)$. At each sampling period, 1 -way ANOVAs were performed to identify any differences between the 3 temperature treatments. Tukey's post hoc comparisons were employed to detect the location of any significant changes over time or between treatments $(\alpha=0.05)$. To determine if the assumptions of the parametric ANOVAs were satisfied, the KolmogorovSmirnov normality test and Levene's homogeneity of variance test were used. SPSS statistical software (version 14.0.0) was used to perform these analyses.

\section{RESULTS}

A significant decline in $\Phi_{\mathrm{PSII}}$ of the in hospite zooxanthellae was found over the length of the experiment ( $p=0.002$; Fig. 1). The $\Phi_{\text {PSII }}$ gradually decreased from 0.67 while the coral was held at $28^{\circ} \mathrm{C}$, to 0.44 after $12 \mathrm{~h}$ 
at $32^{\circ} \mathrm{C}$. Following the dark period from $12-24 \mathrm{~h}, F_{\mathrm{v}} / F_{\mathrm{m}}$ was determined and had not significantly changed from the previous $\Phi_{\text {PSII }}$ measurement, although after $36 \mathrm{~h}$, which included a further $12 \mathrm{~h}$ of light, the $\Phi_{\text {PSII }}$ had dropped to 0.20 . Prior to temperature ramping, the in hospite zooxanthellae density was $3.17 \times 10^{6} \mathrm{~cm}^{-2}$ $( \pm 0.44 \mathrm{SE})$ and by $36 \mathrm{~h}$ this had reduced to $0.64 \times$ $10^{6} \mathrm{~cm}^{-2}( \pm 0.19)$.

The $F_{\mathrm{v}} / F_{\mathrm{m}}$ and $\Phi_{\mathrm{PSII}}$ of the expelled zooxanthellae populations is shown in Fig. 2. The zooxanthellae expelled between 0 and 6 h (Fig. 2a) had an initial $\Phi_{\text {PSII }}$ of 0.37 . In all temperature treatments, there was a significant decline in $F_{\mathrm{v}} / F_{\mathrm{m}}$ and $\Phi_{\mathrm{PSII}}$ up to $96 \mathrm{~h}(\mathrm{p}<0.001)$. At $12 \mathrm{~h}$, the zooxanthellae in the $28^{\circ} \mathrm{C}$ treatment had a higher $\Phi_{\text {PSII }}$ than those at $32^{\circ} \mathrm{C}$, with the $30^{\circ} \mathrm{C}$ treatment falling into both groups $(p=0.009)$. This also occurred for measurements of $F_{\mathrm{v}} / F_{\mathrm{m}}$ at 24 and $48 \mathrm{~h}$ ( $\mathrm{p}=0.010$ and 0.041 , respectively). At the other time intervals, no significant differences were found among the 3 temperature treatments $(\mathrm{p}>0.05)$. By $72 \mathrm{~h}$, the $F_{\mathrm{v}} / F_{\mathrm{m}}$ of the zooxanthellae in the 30 and $32^{\circ} \mathrm{C}$ treatments had reached 0 , and by $96 \mathrm{~h}$ this also occurred in the $28^{\circ} \mathrm{C}$ treatment.

Zooxanthellae expelled between 6 and $12 \mathrm{~h}$ after reaching $32^{\circ} \mathrm{C}$ (Fig. 2b) also showed a steep decline in $F_{\mathrm{v}} / F_{\mathrm{m}}$ and $\Phi_{\mathrm{PSII}}$ following expulsion in all temperature

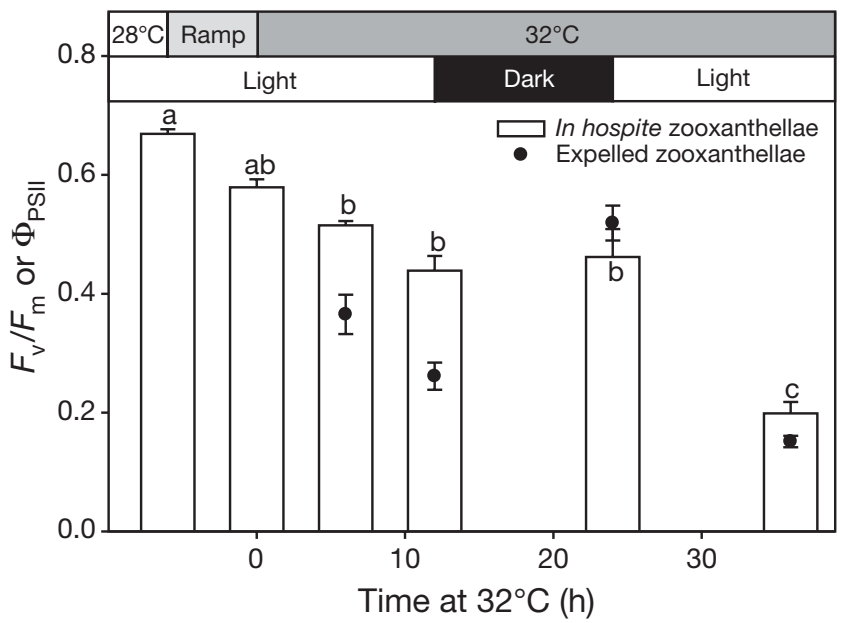

Fig. 1. Maximum $\left(F_{\mathrm{v}} / F_{\mathrm{m}}\right)$ or effective quantum yield $\left(\Phi_{\mathrm{PSII}}\right)$ of in hospite (bars) and expelled (circles) zooxanthellae of Pocillopora damicornis during experimental treatments. $\Phi_{\mathrm{PSII}}$ measurements were taken prior to temperature ramping, once the temperature reached $32^{\circ} \mathrm{C}(0 \mathrm{~h})$ and at 6,12 and $36 \mathrm{~h} . F_{\mathrm{v}} / F_{\mathrm{m}}$ measurements were taken at $24 \mathrm{~h}$ following overnight darkness. The top bar indicates the temperature regime (white $=$ $28^{\circ} \mathrm{C}$, grey $=$ ramp, dark grey $=32^{\circ} \mathrm{C}$ ) and the second bar indicates the light regime (white $=$ light, black $=$ dark) over the experiment. Light intensity $=400 \mu \mathrm{mol}$ photons $\mathrm{m}^{-2} \mathrm{~s}^{-1}$. Mean $\pm \mathrm{SE}(\mathrm{n}=4)$. Letters indicate statistically distinct groups of in hospite zooxanthellae measurements from Tukey's post hoc comparison tests

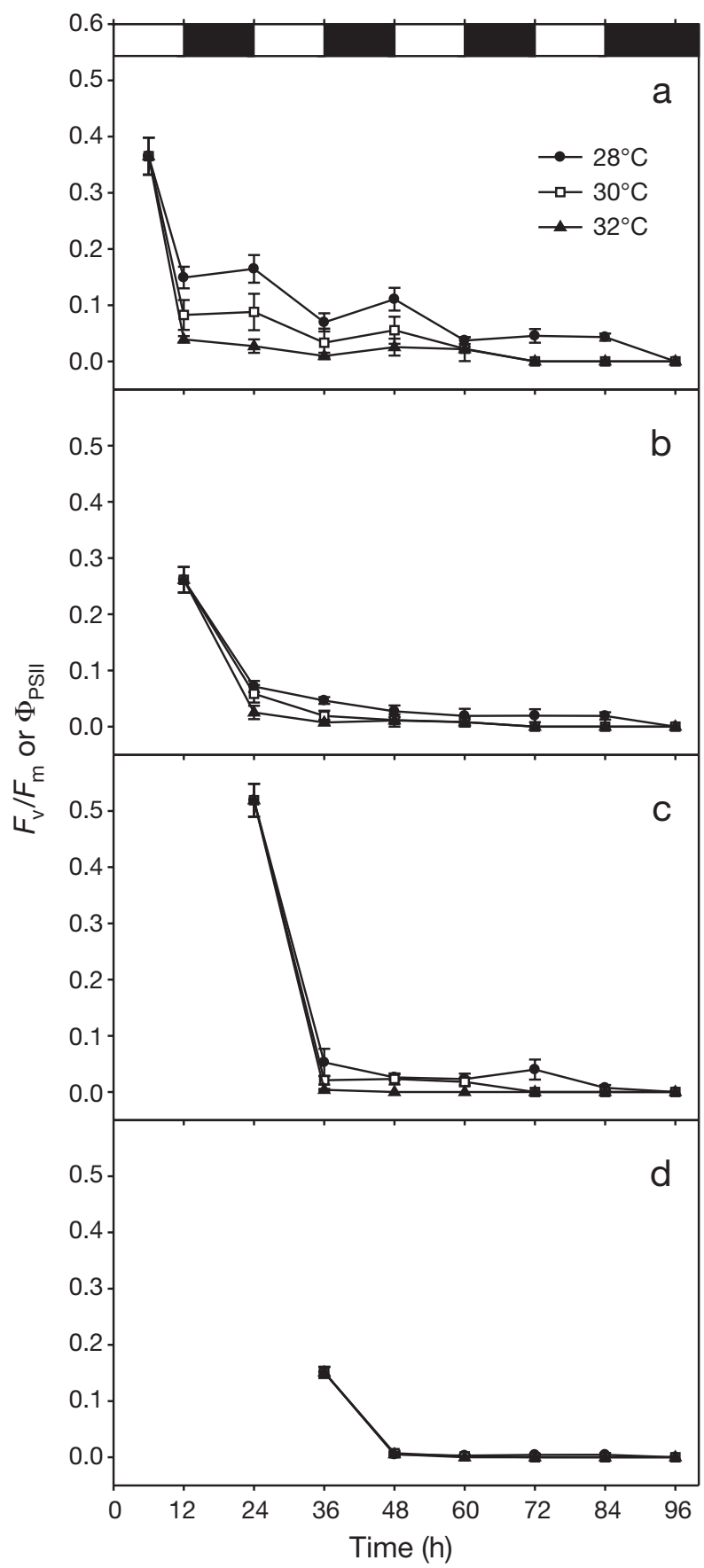

Fig. 2. Maximum $\left(F_{\mathrm{v}} / F_{\mathrm{m}}\right)$ or effective quantum yield $\left(\Phi_{\mathrm{PSII}}\right)$ of expelled zooxanthellae in each of the 4 populations: (a) 0-6 h, (b) 6-12 h, (c) $12-24 \mathrm{~h}$ and $24-36 \mathrm{~h}(\mathrm{~d})$. $\Phi_{\text {PSII }}$ was measured at $6,12,36,60$ and $84 \mathrm{~h}$, while $F_{\mathrm{v}} / F_{\mathrm{m}}$ was measured at $24,48,72$ and $96 \mathrm{~h}$. Therefore the first data points in (a), (b) and (d) are $\Phi_{\text {PSII }}$, while the first data point in (c) is $F_{\mathrm{v}} / F_{\mathrm{m}}$. Measurements on zooxanthellae from the 28,30 and $32^{\circ} \mathrm{C}$ treatments are shown from the time of expulsion up until $96 \mathrm{~h}$. The top bar indicates the light regime over the experiment $($ white $=$ light, black $=$ dark). Light intensity $=$ $400 \mu \mathrm{mol}$ photons $\mathrm{m}^{-2} \mathrm{~s}^{-1}$ during initial expulsion and $100 \mu \mathrm{mol}$ photons $\mathrm{m}^{-2} \mathrm{~s}^{-1}$ at other time periods. Mean $\pm \mathrm{SE}$ $(\mathrm{n}=4)$ 
treatments $(p<0.001)$. Throughout the remainder of the experimental period, all 3 temperature treatments were found to be similar ( $p>0.1)$, except at $36 \mathrm{~h}$ where the $28^{\circ} \mathrm{C}$ treatment was significantly higher than the others $(\mathrm{p}=0.008)$. By $72 \mathrm{~h}$, the zooxanthellae in the 30 and $32^{\circ} \mathrm{C}$ treatments had reached a $F_{\mathrm{v}} / F_{\mathrm{m}}$ of 0 , as did the $28^{\circ} \mathrm{C}$ treatment by $96 \mathrm{~h}$.

The population of zooxanthellae expelled from the coral during the dark period (between 12 and $24 \mathrm{~h}$; Fig. 2c), had an initial $F_{\mathrm{v}} / F_{\mathrm{m}}$ of 0.52 . After $12 \mathrm{~h}$ of light, the $\Phi_{\text {PSII }}$ of all 3 temperature treatments was between 0.01 and 0.05 and did not recover $(p<0.001)$. The $32^{\circ} \mathrm{C}$ treatment reached an $F_{\mathrm{v}} / F_{\mathrm{m}}$ of 0 at $48 \mathrm{~h}$, the $30^{\circ} \mathrm{C}$ treatment at $72 \mathrm{~h}$ and the $28^{\circ} \mathrm{C}$ treatment at $96 \mathrm{~h}$, although no significant differences were found between any of the 3 temperature treatments at each time interval $(\mathrm{p}>0.05)$.

In the final zooxanthellae population collected between 24 and $36 \mathrm{~h}$ (Fig. 2d), the $\Phi_{\text {PSII }}$ upon collection was 0.15 . By $48 \mathrm{~h}, F_{\mathrm{v}} / F_{\mathrm{m}}$ had dropped to 0.01 in all temperature treatments $(\mathrm{p}<0.001)$. Following this time, both $F_{\mathrm{v}} / F_{\mathrm{m}}$ and $\Phi_{\mathrm{PSII}}$ of the 30 and $32^{\circ} \mathrm{C}$ treatments remained at 0 . Although the $28^{\circ} \mathrm{C}$ treatment reached an $F_{\mathrm{v}} / F_{\mathrm{m}}$ of 0 at $96 \mathrm{~h}$, no significant differences among the 3 temperature treatments were found at each time interval $(\mathrm{p}>0.05)$.

Following $F_{\mathrm{v}} / F_{\mathrm{m}}$ and $\Phi_{\mathrm{PSII}}$ measurements, $H_{\mathrm{z}}$ and $D_{\mathrm{z}}$ in each of the 4 populations were monitored over time, based on visual assessments of cell characteristics (Fig. 3). For all 4 expelled zooxanthellae populations $-0-6 \mathrm{~h}$ (Fig. 3a), 6-12 h (Fig. 3b) , 12-24 h (Fig. 3c) and 24-36 h (Fig. 3d) - a gradual, significant decline in the percentage of $H_{z}$ occurred in all 3 temperature treatments over time $(\mathrm{p}<0.001)$. In addition, following the initial collection of expelled cells, the number of $H_{\mathrm{z}}$ was always highest in the $28^{\circ} \mathrm{C}$ treatment, followed by the $30^{\circ} \mathrm{C}$ treatment, and then the $32^{\circ} \mathrm{C}$ treatment.

In the $0-6 \mathrm{~h}$ population (Fig. 3a), $98 \%$ of the expelled zooxanthellae were initially categorised as $H_{\mathrm{z}}$ $97 \%$ in the $6-12 \mathrm{~h}$ population (Fig. 3b), $92 \%$ in the $12-24 \mathrm{~h}$ population (Fig. 3c) and $74 \%$ in the $24-36 \mathrm{~h}$ population (Fig. 3d). In all populations, similar trends were observed in the reduction of $H_{z}$ over time. After $96 \mathrm{~h}$, the $28^{\circ} \mathrm{C}$ treatments had between 29 and $32 \%$ of $\mathrm{H}_{\mathrm{z}}$ in the population, the $30^{\circ} \mathrm{C}$ treatments had 17 to $21 \%$, and the $32^{\circ} \mathrm{C}$ treatments had 10 to $13 \%$.

Zooxanthellae density within the containers was measured when expelled zooxanthellae were collected and compared to the density at $96 \mathrm{~h}$ in each of the 3 temperature treatments (Table 1). Upon collection, the average cell density in each population varied between approximately 15.4 and $16.8 \times 10^{6} \mathrm{ml}^{-1}$. By $96 \mathrm{~h}$, the number of zooxanthellae in each population had declined, with the lowest density in the $32^{\circ} \mathrm{C}$ treat-

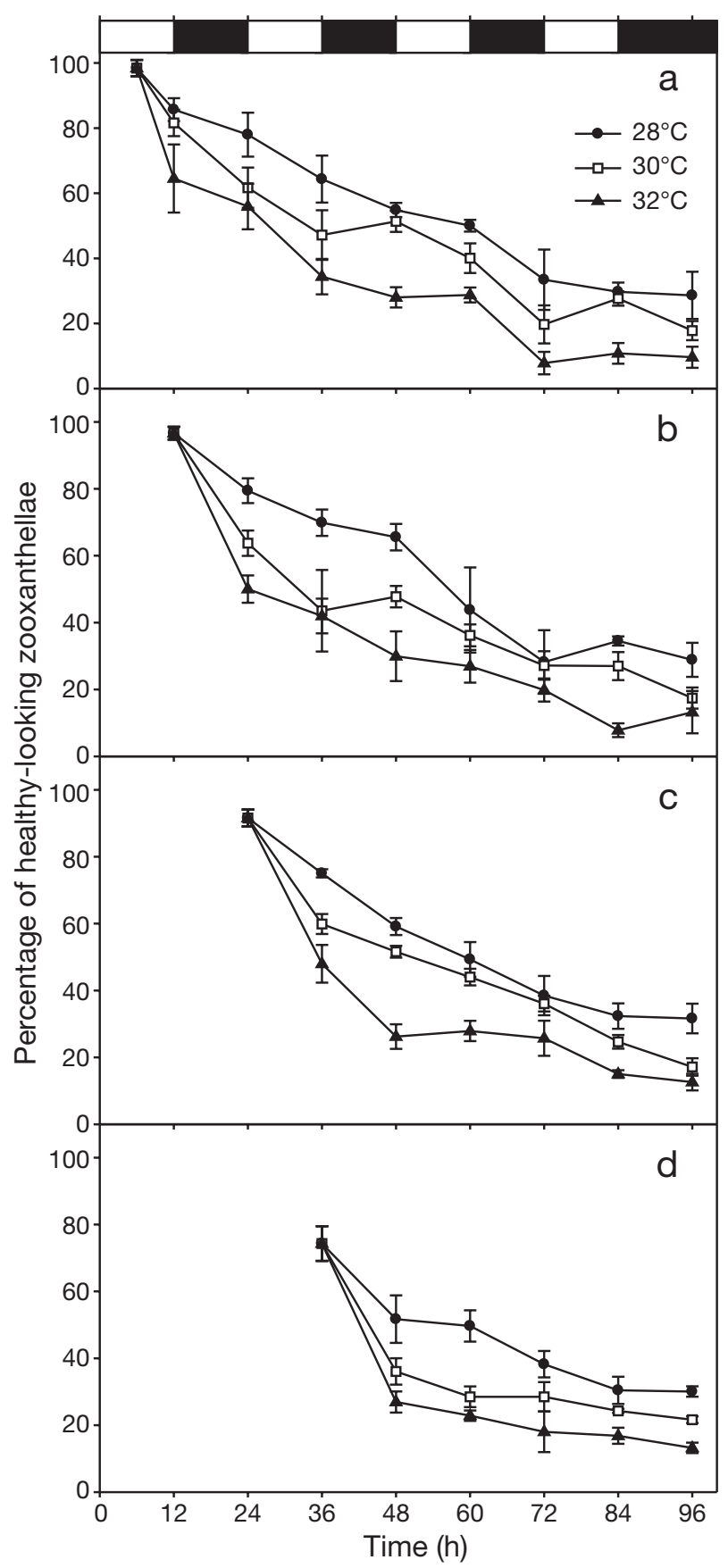

Fig. 3. Percentage of healthy-looking zooxanthellae in the 4 expelled zooxanthellae populations - (a) 0-6 h, (b) 6-12 h, (c) $12-24 \mathrm{~h}$ and (d) $24-36 \mathrm{~h}-$ from the 28,30 and $32^{\circ} \mathrm{C}$ treatments are shown from the time of expulsion up until $96 \mathrm{~h}$. The top bar indicates the light regime over the experiment (white $=$ light, black $=$ dark $)$. Light intensity $=100 \mu \mathrm{mol}$ photons $\mathrm{m}^{-2} \mathrm{~s}^{-1}$. Mean $\pm \mathrm{SE}(\mathrm{n}=4)$

ments $\left(2.5\right.$ to $\left.5.0 \times 10^{6} \mathrm{ml}^{-1}\right)$, followed by the $30^{\circ} \mathrm{C}$ treatments $\left(3.0\right.$ to $6.5 \times 10^{6} \mathrm{ml}^{-1}$ ) and then the $28^{\circ} \mathrm{C}$ treatments (5.5 to $10.5 \times 10^{6} \mathrm{ml}^{-1}$ ). 
Table 1. Zooxanthellae density $\left(\times 10^{6} \mathrm{ml}^{-1}\right)$ for each of the 4 expelled zooxanthellae populations from the time of expulsion (Initial) to the final measurement (Final). Values are mean $\pm \mathrm{SE}(\mathrm{n}=4)$

\begin{tabular}{|c|c|c|c|c|c|}
\hline \multicolumn{2}{|c|}{ Treatmen } & at $0-6 \mathrm{~h}$ & $6-12 \mathrm{~h}$ & $12-24 \mathrm{~h}$ & $24-36 \mathrm{~h}$ \\
\hline \multicolumn{2}{|l|}{ Initial } & $16.8 \pm 4.8$ & $16.1 \pm 2.2$ & $15.4 \pm 4.1$ & $15.5 \pm 3.7$ \\
\hline \multirow[t]{3}{*}{ Final } & $28^{\circ} \mathrm{C}$ & $7.0 \pm 4.4$ & $5.5 \pm 1.5$ & $6.5 \pm 2.9$ & $10.5 \pm 6.5$ \\
\hline & $30^{\circ} \mathrm{C}$ & $6.5 \pm 2.6$ & $5.0 \pm 0.5$ & $3.0 \pm 0.6$ & $6.5 \pm 4.5$ \\
\hline & $32^{\circ} \mathrm{C}$ & $5.0 \pm 2.4$ & $3.5 \pm 0.9$ & $2.5 \pm 0.5$ & $5.5 \pm 2.9$ \\
\hline
\end{tabular}

\section{DISCUSSION}

The post-bleaching viability of expelled zooxanthellae was determined in 4 populations released at different time intervals. A sub-sample of each population was placed in 1 of 3 different temperature treatments upon collection in order to ascertain the capacity for long-term survival of zooxanthellae outside of the host under different temperature conditions. This is the first study of its kind to monitor the longevity and survivorship of expelled zooxanthellae and has also contributed to the knowledge on the functional status of expelled zooxanthellae during thermal bleaching episodes.

The host coral showed signs of bleaching through the decline in symbiont density and the reduction in PSII photosynthetic efficiency as the length of exposure to elevated temperature and high light increased (Fig. 1). The $\Phi_{\text {PSII }}$ of in hospite zooxanthellae was higher than that of expelled zooxanthellae at 6,12 and $36 \mathrm{~h}$ (Fig. 2). This indicates that under bleaching conditions (elevated temperature and high light), the expelled zooxanthellae from the coral Pocillopora damicornis have a lower PSII photosynthetic efficiency than those in hospite. However, at the $24 \mathrm{~h}$ mark, following $12 \mathrm{~h}$ of darkness, there was no significant difference in $F_{\mathrm{v}} / F_{\mathrm{m}}$ between the expelled and in hospite zooxanthellae populations, indicating similar photochemical efficiencies.

This suggests that during bleaching conditions, greater photodamage occurs to zooxanthellae in the expelled population. Whether this damage is manifested prior to expulsion or upon exposure to the vastly different physical and chemical conditions of the water column (Goiran et al. 1997) is unclear from these results. However, the response of the zooxanthellae following the dark period revealed that those retained within the host tissue experienced a similar degree of photosynthetic impairment to those expelled (Figs. 1 \& 2c). This suggests that during thermal bleaching events, light is the driving force behind the loss of PSII photochemical efficiency and cell viability in zooxanthellae expelled into the water column. The relatively high $F_{\mathrm{v}} / F_{\mathrm{m}}$ value for the expelled zooxanthellae population at $24 \mathrm{~h}$ indicates that cells that are able to inhabit a low light environment (such as the sediment) would have greater potential for long-term survival on the reef, as their photosynthetic capacity is higher than those expelled during light exposure. The importance of light in the survivorship of expelled zooxanthellae is further supported by the rises in PSII photochemical efficiency (and subsequent falls) observed after the $12 \mathrm{~h}$ dark periods in the $28^{\circ} \mathrm{C}, 0-6 \mathrm{~h}$ population (Fig. $2 \mathrm{a}$ ).

Upon collection of expelled symbionts at each time interval, the $F_{\mathrm{v}} / F_{\mathrm{m}}$ and $\Phi_{\text {PSII }}$ values provided evidence of photochemical activity (Fig. 2). In addition, the morphological characteristics of these cells suggested that the majority were in a functional state (Fig. 3). This provides support for the results of Ralph et al. $(2001,2005)$ and Bhagooli \& Hidaka (2004b), who demonstrated the viability of these expelled symbionts during simulated bleaching events. However, soon after expulsion, these cells gradually began to degrade (Fig. 3) and quickly lost their ability to photosynthesise, with PSII photochemical efficiency falling dramatically within $12 \mathrm{~h}$ following collection in all post-bleaching temperature treatments (Fig. 2). Franklin et al. (2004) concluded that expelled zooxanthellae were removed by the host as they had died and degenerated in hospite. This was based on measurements of plasma membrane integrity and the chlorotic nature of the zooxanthellae cells from the coral Stylophora pistillata. In contrast to that conclusion, we have shown here that it is not until after initial expulsion into the water column that zooxanthellae begin to degrade. Possible reasons for these conflicting results include the different host corals used, which can respond differently to bleaching conditions, where the proportion of healthy zooxanthellae expulsion can vary with time (i.e. the frequency of healthy cells expelled from $S$. pistillata may differ from Pocillopora damicornis; Ralph et al. 2005), or that there were differences in the speed of cell viability assessment following expulsion. If it were the latter, the results of Franklin et al. (2004) would correlate well with our results, as PSII photochemical efficiency and morphological condition were quickly lost after initial expulsion.

The capacity for expelled zooxanthellae photosynthetic survival depended on the time of expulsion from the host following the onset of bleaching conditions, as well as the water temperature to which these zooxanthellae were exposed following expulsion (Fig. 2). Those expelled earlier had a photosynthetic longevity that outlasted those expelled later during the bleaching treatment. This supports the findings of Ralph et al. (2005), who showed that most photosynthetically healthy zooxanthellae are expelled within the first few hours of bleaching in Pocillopora damicornis. Here, we 
found that the healthiest population of zooxanthellae were those expelled between 0 and $6 \mathrm{~h}$ at $28^{\circ} \mathrm{C}$, with the unhealthiest in the $24-36 \mathrm{~h}$ population held at $32^{\circ} \mathrm{C}$. Although the samples held at $28^{\circ} \mathrm{C}$ were healthier for longer than those at 30 and $32^{\circ} \mathrm{C}$, measurements of PSII photochemical efficiency and morphological condition revealed that this was short-lived, with the maximum length of survival being $5 \mathrm{~d}$. The increase in PSII photochemical efficiency in the $0-6 \mathrm{~h}$ population at $28^{\circ} \mathrm{C}$ following periods of darkness suggests that the light exposure $\left(100 \mu \mathrm{mol}\right.$ photons $\left.\mathrm{m}^{-2} \mathrm{~s}^{-1}\right)$ was a significant contributor to the photosynthetic degradation of cells (Bhagooli \& Hidaka 2003). It therefore follows that if expelled zooxanthellae were to inhabit a lowerlight environment, survivorship may well be improved.

Following the single cell measurements of Ralph et al. (2001), Bhagooli \& Hidaka (2004b) recognised the importance of assessing the morphological condition of the population of expelled zooxanthellae, as well as determining their PSII photosynthetic efficiency. Here we found that PSII photosynthetic efficiency and percent of $H_{\mathrm{z}}$ followed similar trends, although the speed of decline in $\Phi_{\text {PSII }}$ was much greater than the decline in the proportion of $H_{\mathrm{z}}$. By $5 \mathrm{~d}$, all treatments had an $F_{\mathrm{v}} / F_{\mathrm{m}}$ of 0 (Fig. 2), yet the percent of $H_{\mathrm{z}}$ varied between 10 and $32 \%$ (Fig. 3). This decline in cellular structural integrity was the probable cause for the considerable loss of symbionts over time in the holding containers (Table 1), as the $5 \mu \mathrm{m}$ mesh would have contained the intact cells, but allowed for the exit of degraded zooxanthellae particles. A possible reason for the disparity in the rate of decline in $F_{\mathrm{v}} / F_{\mathrm{m}}$ and $\Phi_{\mathrm{PSII}}$ and the loss of $H_{\mathrm{z}}$ may be that measures of PSII photochemical efficiency are a more sensitive index of cellular damage than morphology, or that the photosynthetic apparatus of zooxanthellae is more vulnerable to bleaching conditions than other cellular components. In addition, the site of initial photochemical damage may be a single site along the photosynthetic chain of events and a visual manifestation of this damage may take longer to appear. For example, the oxygen evolving complex (Iglesias-Prieto 1997), PSII reaction centres (Warner et al. 1999, Takahashi et al. 2004, Hill \& Ralph 2006) and dark-reactions (Jones et al. 1998) have been proposed as impact sites. These forms of sub-cellular damage would be reflected in measurements of $F_{\mathrm{v}} / F_{\mathrm{m}}$ and $\Phi_{\text {PSII }}$, but could not be detected through the light microscopy techniques also used here. Cells may have appeared intact, whereas this may not have been entirely correct with regards to photochemical reactions in the chloroplasts. Further work is required into the degradation of cellular components as a secondary or knock-on effect, which becomes clear after the initial impact.

These results suggest that the long-term viability of expelled zooxanthellae in the water column is limited to a matter of days. The length of zooxanthellae survival is dependent on the timing of expulsion and subsequent water temperatures and light intensity. If seawater temperatures drop to normal summer-time levels shortly after the onset of bleaching, expelled zooxanthellae will have a greater chance of survival. Photosynthetic efficiency of PSII declined much faster than the visible structural integrity of the cells, and after $5 \mathrm{~d}$, the potential for survival seemed lost. Unless zooxanthellae have the capacity to survive in other environments of coral reefs (such as the sediment), their ability to act as a source of symbionts for re-infection following a bleaching event seems minimal.

Acknowledgements. Australian Research Council Discovery Grant number DP0558946 supported this project. This research was performed under GBRMPA permit number G03/12019.1. This is contribution number 218 from the Institute for Water and Environmental Resource Management.

\section{LITERATURE CITED}

Baker AC (2001) Reef corals bleach to survive change. Nature 411:765-766

Belda-Baillie CA, Sison M, Silvestre V, Villamor K, Monje V, Gomez ED, Baillie BK (1999) Evidence for changing symbiotic algae in juvenile tridacnids. J Exp Mar Biol Ecol 241:207-221

Berkelmans R, van Oppen MJH (2006) The role of zooxanthellae in the thermal tolerance of corals: a 'nugget of hope' for coral reefs in an era of climate change. Proc R Soc Lond B 273:2305-2312

Bhagooli R, Hidaka M (2003) Comparison of stress susceptibility of in hospite and isolated zooxanthellae among five coral species. J Exp Mar Biol Ecol 291:181-197

Bhagooli R, Hidaka M (2004a) Photoinhibition, bleaching susceptibility and mortality in two scleractinian corals, Platygyra ryukyuensis and Stylophora pistillata, in response to thermal and light stresses. Comp Biochem Physiol A 137: $547-555$

Bhagooli R, Hidaka M (2004b) Release of zooxanthellae with intact photosynthetic activity by the coral Galaxea fascicularis in response to high temperature stress. Mar Biol 145: 329-337

Brown BE, Tissier MDA, Bythell JC (1995) Mechanisms of bleaching deduced from histological studies of reef corals sampled during a natural bleaching event. Mar Biol 122: 655-663

Carlos AA, Baillie BK, Kawachi M, Maruyama TA (1999) Phylogenetic position of Symbiodinium (Dinophyceae) isolates from Tridacnids (Ivalvia), Cardiids (Ivalvia), a sponge (Porifera), a soft coral (Anthozoa), and a free-living strain. J Phycol 35:1054-1062

Coles SL, Brown BE (2003) Coral bleaching-capacity for acclimatization and adaptation. Adv Mar Biol 46:183-223

Franklin DJ, Hoegh-Guldberg O, Jones RJ, Berges JA (2004) Cell death and degeneration in the symbiotic dinoflagellates of the coral Stylophora pistillata during bleaching. Mar Ecol Prog Ser 272:117-130

Franklin DJ, Molina Cedres CM, Hoegh-Guldberg O (2006) Increased mortality and photoinhibition in the symbiotic dinoflagellates of the Indo-Pacific coral Stylophora pistillata (Esper) after summer bleaching. Mar Biol 149: 633-642 
Franzisket L (1970) The atrophy of hermatypic reef corals maintained in darkness and their subsequent regeneration in light. Int Rev Gesamten Hydrobiol 55:1-12

Gates RD, Baghdasarian G, Muscatine L (1992) Temperature stress causes host cell detachment in symbiotic cnidarians: implications for coral bleaching. Biol Bull (Woods Hole) 182: 324-332

Goiran C, Allemand D, Galgani I (1997) Transient Na+ stress in symbiotic dinoflagellates after isolation from coral-host cells and subsequent immersion in seawater. Mar Biol 129: 581-589

Hayes RL, Bush PG (1990) Microscopic observations of recovery in the reef-building scleractinian coral, Montastrea annularis, after bleaching on a Cayman reef. Coral Reefs 8: 203-209

Hill M, Wilcox T (1998) Unusual mode of symbiont repopulation after bleaching in Anthosigmella varians: acquisition of different zooxanthellae strains. Symbiosis 25:279-289

Hill R, Ralph PJ (2006) Photosystem II heterogeneity of in hospite zooxanthellae in scleractinian corals exposed to bleaching conditions. Photochem Photobiol 82:1577-1585

Hoegh-Guldberg O (1999) Climate change, coral bleaching and the future of the world's coral reefs. Mar Freshw Res 50: 839-866

Hoegh-Guldberg O, Smith GJ (1989) The effect of sudden changes in temperature, light and salinity on the population density and export of zooxanthellae from the reef corals Stylophora pistillata Esper and Seriatopora hystrix Dana. J Exp Mar Biol Ecol 129:279-303

Hoegh-Guldberg O, Jones RJ, Ward S, Loh WK (2002) Is coral bleaching really adaptive? Nature 415:601-602

Iglesias-Prieto R (1997) Temperature-dependent inactivation of Photosystem II in symbiotic dinoflagellates. In: Lessios HA, Macintyre IG (eds) Proc 8th Int Coral Reef Symp. Smithsonian Tropical Research Institute, Panama, p 1313-1318

Jokiel PL, Coles SL (1990) Response of Hawaiian and other Indo-Pacific reef corals to elevated temperature. Coral Reefs 8:155-162

Jones RJ, Hoegh-Guldberg O (2001) Diurnal changes in the photochemical efficiency of the symbiotic dinoflagellates (Dionphyceae) of corals: photoprotection, photoinactivation and the relationship to coral bleaching. Plant Cell Environ 24:89-99

Jones RJ, Yellowlees D (1997) Regulation and control of intracellular algae (= zooxanthellae) in hard corals. Phil Trans R Soc Lond B 352:457-468

Editorial responsibility: Otto Kinne (Editor-in-Chief), Oldendorf/Luhe, Germany
Jones RJ, Hoegh-Guldberg O, Larkum AWD, Schreiber U (1998) Temperature-induced bleaching of corals begins with impairment of the $\mathrm{CO}_{2}$ fixation metabolism in zooxanthellae. Plant Cell Environ 21:1219-1230

Kinzie RA, III, Takayama M, Santos SR, Coffroth MA (2001) The adaptive bleaching hypothesis: experimental tests of critical assumptions. Biol Bull (Woods Hole) 200:51-58

LaJeunesse TC (2001) Investigating the biodiversity, ecology and phylogeny of endosymbiotic dinoflagellates in the genus Symbiodinium using the ITS region: in search of a 'species' level marker. J Phycol 37:866-880

Lewis CL, Coffroth MA (2004) The acquisition of exogenous algal symbionts by an octocoral after bleaching. Science 304:1490-1492

Muller-Parker G (1984) Dispersal of zooxanthellae on coral reefs by predators on cnidarians. Biol Bull (Woods Hole) 167:159-167

Ralph PJ, Gademann R, Larkum AWD (2001) Zooxanthellae expelled from bleached corals at $33^{\circ} \mathrm{C}$ are photosynthetically competent. Mar Ecol Prog Ser 220:163-168

Ralph PJ, Larkum AWD, Kuhl M (2005) Temporal patterns in effective quantum yield of individual zooxanthellae expelled during bleaching. J Exp Mar Biol Ecol 316:17-28

Richmond RH, Hunter CL (1990) Reproduction and recruitment of corals: comparisons among the Caribbean, the Tropical Pacific, and the Red Sea. Mar Ecol Prog Ser 60:185-203

Stimson J, Kinzie RA (1991) The temporal pattern and rate of release of zooxanthellae from the reef coral Pocillopora damicornis (Linnaeus) under nitrogen-enriched and control conditions. J Exp Mar Biol Ecol 153:63-74

Takahashi S, Nakamura T, Sakamizu M, van Woesik R, Yamasaki H (2004) Repair machinery of symbiotic photosynthesis as the primary target of heat stress for reefbuilding corals. Plant Cell Physiol 45:251-255

Tchernov D, Gorbunev MY, de Vargas C, Yadav SN, Milligan AJ, Haggblom M, Falkowski PG (2004) Membrane lipids of symbiotic algae are diagnostic of sensitivity to thermal bleaching in corals. Proc Natl Acad Sci USA 101: 13531-13535

Titlyanov EA, Titlyanova TV, Leletkin VA, Tsukahara J, van Woesik R, Yamazato K (1996) Degradation of zooxanthellae and regulation of their density in hermatypic corals. Mar Ecol Prog Ser 139:167-178

Warner ME, Fitt WK, Schmidt GW (1999) Damage to Photosystem II in symbiotic dinoflagellates: a determinant of coral bleaching. Proc Natl Acad Sci USA 96:8007-8012

Submitted: March 12, 2007; Accepted: July 16, 2007

Proofs received from author(s): November 28, 2007 